\title{
An Approach For Optimum Utilization Of Excess Water Available During Excavation At Construction Sites
}

\author{
Preyansh Gupta $^{1}$, Krutuja Jagtap ${ }^{2}$, Mrs. V. U. Khanapure ${ }^{3}$ \\ Department Of Civil Engineering, Sinhgad College Of Engineering, Pune, Maharashtra, India
}

\begin{abstract}
Ground water is considered as primary source of water for construction usage. Due to deep excavation and higher water level many times, the availability of water is quite more than the requirement for construction purpose which results in huge wastage of water. It initiates proper analysis of water availability and its management for other purpose to cope up with a current water requirement. There should be proper water management system considering improved reusability aspects. To understand scope of project we have conducted case study of project "SUVARNREKHA DINNING HALL, PUNE." we studied primarily the ground water table of the area and collected water from different location of site having excavation $12 \mathrm{~m}$ deep. Methodologies adopted consist of various tests like $\mathrm{pH}$, Alkalinity, Hardness test which are required for testing basic quality of water. The results obtained from the test aresatisfying the standard condition as specified byBIS, GOI, WHO.Thus, we can utilize the ground water from the site for various purposes like, curing, household purpose, water proofing, government infrastructure landscape, industrial purposes, or for other construction sites. By adopting above mentioned perception of ground water utility green credits can be earned by builder/client/construction group from LEED, TERI, IGBS, and GRIHA. etc. Furthermore we have visited several sites around Pune, to study the yield of water, requirement of water for construction purposes and wastage of water out of which 5 sites are selected for the execution of this project. Extra available water can be used for other purposes. It can become economically viable option for a firm along with improved market image.
\end{abstract}

\section{Introduction}

The construction industry is the second largest industry of the country after agriculture. It is an integral part of country's infrastructure and industrial development and is poised for further growth on account of industrialization, urbanization, economic development and improved quality of living. The construction industry is the infrastructure of the infrastructure industry. Considered as the building blocks of development, construction has played a vital role in the transformation of India, catering to its infrastructural needs. Due to high rise construction, excavation is the preliminary step needed for the further construction so as to make the high rise structure stand stiff and stable. Approximately 4-6 m deep excavation inside the earth surface with high ground water table availability of ground water will be more. Many construction industries do not make any specific provision or no proper system is adopted to store and utilize that ground water for some other purposes.

As the corporation and other regulatory bodies won't have any control over this hence there is huge wastage of water. Hence we should have proper system for analysis of excess water and it should be mandatory for the firm to store this excess water and divert it for some other useful purposes.

\subsection{Aim Of Present Study}

\section{Aim And Objective}

To assess the potential for utilization for ground water to overcome the scarcity and to reduce the wastage of water in Pune Municipal Corporation region.

\subsection{Objectives Of Present Study}

To study optimum utilization of ground water which is available due to deep excavation during construction.

To propose probable utilization of excess water resulted due to deep excavation for other purposes.

To assist the feasibility of excess water for domestic purposes to cope up with current water requirements.

\section{Methodology}

There are many residential /commercial construction going on in Pune city. Amongst them few sites are identified for execution. 
An Approach For Optimum Utilization Of Excess Water Available During Excavation At..

Table 1: Sites for Execution

\begin{tabular}{|l|l|l|}
\hline Sr. No. & Name & Location \\
\hline 1. & West Brook (TARA CONSTRUCTION) & Ambegaon \\
\hline 2. & Sukh Niwas (TARA CONSTRUCTION) & Mangalwar Peth \\
\hline 3. & Kubhar Mathwad & Kothrud \\
\hline 4. & Elanza & Tukai Nagar \\
\hline 5. & Suvarnarekha & Prabhat Road \\
\hline
\end{tabular}

To compute test results the water sample is being collected by various identified sites. Then the water sample is being submitted to GSDA (Groundwater Survey and Development Agency) for test results, furthermore the obtained experimental results are compared with standard results by BIS (Bureau of Indian Standards).

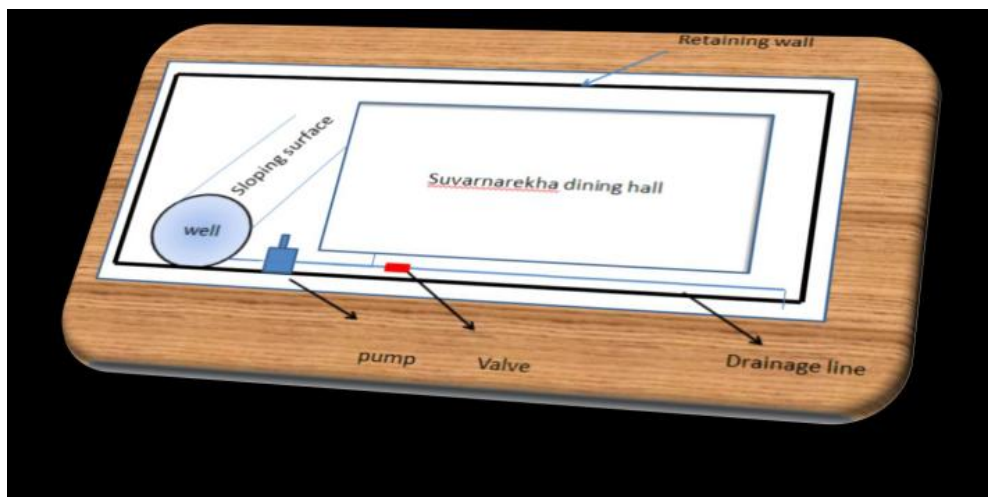

Fig.1 Actual Site Condition

Now as per the current situation surplus amount of water is being wasted. To avoid this wastage the provision have been made i.e. to divert the excess water to the nearby area with the help of water tankers or suitable distribution systems which helps to use theexcess amount of water for other useful purposes. A provision of valve is to be made which will function according to the signals given by the circuit i.e. IC 55, which indicate the desirable water level in the ring well.

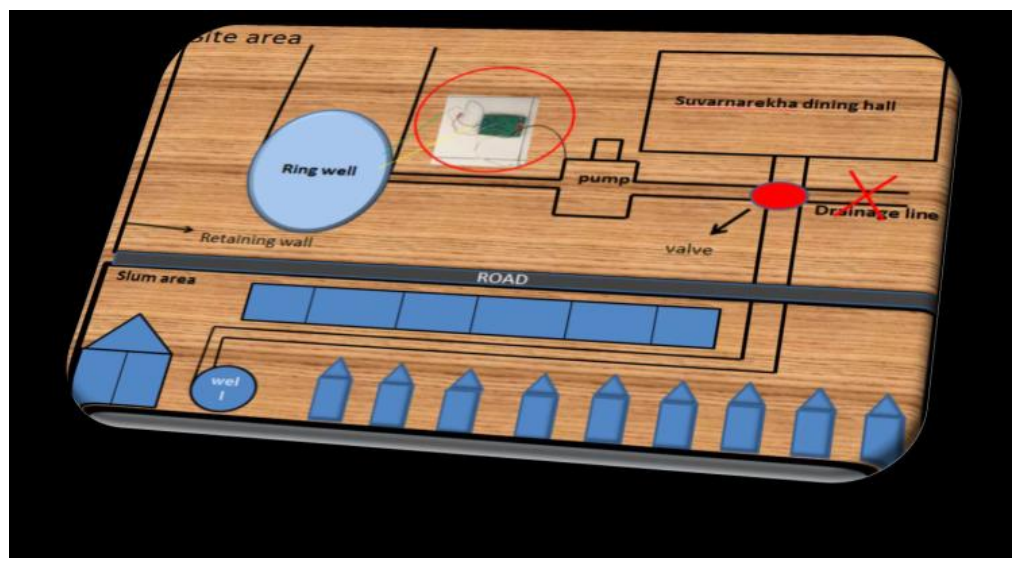

Fig.2 Modified Site View

\subsection{Chemical Analysis Results}

\section{Results And Discussions}

Table 2
\begin{tabular}{|l|l|l|l|l|l|}
\hline SN & $\mathrm{pH}$ & COND & TDS & TH & CA \\
\hline & & $\mathrm{mg} / \mathrm{m}$ & $\mathrm{mg} / \mathrm{l}$ & $\mathrm{mg} / \mathrm{l}$ & $\mathrm{mg} / \mathrm{l}$ \\
\hline 1 & 7.6 & 653 & 418 & 292 & 66 \\
\hline 2 & 7.4 & 748 & 479 & 348 & 93 \\
\hline 3 & 7.4 & 754 & 483 & 300 & 85 \\
\hline 4 & 7.42 & 740 & 474 & 316 & 94 \\
\hline 5 & 7.5 & 562 & 360 & 236 & 61 \\
\hline 6 & 7.2 & 692 & 443 & 328 & 77 \\
\hline
\end{tabular}


Table 3

\begin{tabular}{|l|l|l|l|l|l|}
\hline SN & MG & TALK & CO3 & HCO3 & CL \\
\hline & $\mathrm{mg} / \mathrm{l}$ & $\mathrm{mg} / \mathrm{l}$ & $\mathrm{mg} / \mathrm{l}$ & $\mathrm{mg} / \mathrm{l}$ & $\mathrm{mg} / \mathrm{l}$ \\
\hline 1 & 38 & 244 & 0 & 244 & 42 \\
\hline 2 & 35 & 320 & 0 & 320 & 94 \\
\hline 3 & 26 & 284 & 0 & 284 & 58 \\
\hline 4 & 24 & 288 & 0 & 288 & 42 \\
\hline 5 & 25 & 180 & 0 & 180 & 44 \\
\hline 6 & 41 & 140 & 0 & 140 & 62 \\
\hline
\end{tabular}

Table 4

\begin{tabular}{|l|l|l|l|l|}
\hline SN & NA & K & NO3 & F ppm \\
\hline & $\mathrm{mg} / \mathrm{l}$ & $\mathrm{mg} / \mathrm{l}$ & $\mathrm{mg} / \mathrm{l}$ & $\mathrm{mg} / \mathrm{l}$ \\
\hline 1 & 23.5 & 1.8 & 2 & 0.67 \\
\hline 2 & 38.2 & 0.4 & 1 & 0.29 \\
\hline 3 & 38.4 & 0.4 & 1 & 0.33 \\
\hline 4 & 20.3 & 2.2 & 12 & 0.17 \\
\hline 5 & 19.7 & 1.6 & 23 & 0.11 \\
\hline 6 & 19.6 & 1.9 & 20 & 0.21 \\
\hline
\end{tabular}

The summary of ground water test results are indicated by tables $1,2 \& 3$ and the results are compared with the standards from BIS (Bureau of Indian Standards) that is indicated in table $5 \& 6$ below.

Table 5

\begin{tabular}{|l|l|l|l|l|l|}
\hline & $\mathrm{pH}$ & $\mathrm{TDS}$ & $\mathrm{TH}$ & $\mathrm{CA}$ & $\mathrm{MG}$ \\
\hline & & $\mathrm{mg} / \mathrm{l}$ & $\mathrm{mg} / \mathrm{l}$ & $\mathrm{mg} / \mathrm{l}$ & $\mathrm{mg} / \mathrm{l}$ \\
\hline $\begin{array}{l}\text { Drinking } \\
\text { Water }\end{array}$ & $\begin{array}{l}6.5- \\
8.5\end{array}$ & 500 & 300 & 75 & 30 \\
\hline
\end{tabular}

Table 6

\begin{tabular}{|l|l|l|l|l|l|}
\hline & TALK & $\mathrm{CO} 3$ & $\mathrm{HCO} 3$ & $\mathrm{CL}$ & $\mathrm{NO} 3$ \\
\hline & $\mathrm{mg} / \mathrm{l}$ & $\mathrm{mg} / \mathrm{l}$ & $\mathrm{mg} / \mathrm{l}$ & $\mathrm{mg} / \mathrm{l}$ & $\mathrm{mg} / \mathrm{l}$ \\
\hline $\begin{array}{l}\text { Drinking } \\
\text { Water }\end{array}$ & $200-600$ & 0 & $200-600$ & 25 & 45 \\
\hline
\end{tabular}

\section{Conclusion}

There is very low level of awareness and regulation about utilization of ground water for various purpose.

- Efficiency of utilization in all the industrial uses of water should be optimized and an awareness of water as a scarce resource should be fostered.

- Conservation consciousness should be promoted through education, regulation, incentives and disincentives.

- The key to the problem lies in effective management of water so obtained. Suitable measures including improved process technology such as use of filters, distribution systems whichever economical.

\section{Reference}

[1]. Michael Mamlouk\& John Zaniewski (1999): Materials for Civil and Construction Engineers,Addison Wesley Longman, Inc.,

[2]. http://en.wikipedia.org/wiki/Groundw-ater

[3]. http://www.wisegeek.com/what-are-the-different-types-of-groundwater-problems.htm

[4]. McCormack, Michael. Treloar, Graham J., Palmowski, Laurence and Crawford, Robert."Modeling Direct and Indirect Water Requirements of Construction”,Build. Res. Inform., Vol. 35, 2007, p 156-162.

[5]. Crawford, Robert H. and Treloar, Graham J., "An Assessment of the Energy and Water Embodied in commercial Building Construction", Australian Life Cycle Assessment Conference, Sydney, N.S.W., 2005, p.1-10.McCormack, Michael. Treloar, Graham J., Palmowski.

[6]. www.ijset.in 